\title{
IMPLEMENTASI DANA DESA DALAM PELAKSANAAN PEMBANGUNAN DESA DAN PEMBERDAYAAN MASYARAKAT \\ (Best Practice di Desa Kancilan Tahun 2017)
}

\author{
Ummi Mahbubah, Suparnyo dan Subarkah \\ Email : mahbubah.sangperindu@gmail.com, suparnyo@umk.ac.id, \\ subarkah_sh@yahoo.com \\ Fakultas Hukum Universitas Muria Kudus
}

\begin{abstract}
ABSTRAK
Undang-Undang Nomor 4 tahun 2014 Tentang Desa memberikan amanat penerimaan Dana Desa untuk setiap desa se-Indonesia, dana desa tersebut dapat digunakan oleh pemerintah desa untuk membiayai pembangunan desa dan pemberdayaan masyarakat. Namun sebelum dana desa digunakan seluruh kegiatan baik pembangunan desa maupun pemberdayaan masyarakat, seluruh perencanaan harus masuk dalam dokumen perencanaan desa yang tertuang dalam Rencana Pembangunan Jangka Menengah Desa (RPJMDesa) dan dokumen Rencana Kerja Pemerintah Desa (RKPDesa).
\end{abstract}

Kata Kunci: Dana Desa, Pembangunan Desa, Pemberdayaan Masyarakat 


\section{PENDAHULUAN}

Indonesia merupakan negara kepulauan terbesar di dunia, yang terdiri 17.504 pulau, dengan jumlah penduduk terbesar ke empat dunia dengan populasi 270.054.853 juta jiwa ${ }^{51}$, dari Sabang sampai Merauke Indonesia mempunyai suku, ras, agama dan bahasa yang beragam, namun keberagaman itu menjadikan ciri khas Indonesia. Selain itu kawasan di Indonesia juga sangat beragam.

Data terakhir tahun 2012 menunjukkan ada 415 kabupaten, 93 kota dalam 34 provinsi di Indonesia serta mempunyai 6.793 kecamatan, 79.075 kelurahan atau desa ${ }^{52}$. Desa sebagai pemerintahan yang bersinggungan langsung dengan masyarakat menjadi perhatian khusus pemerintah pusat Hal ini dikarenakan sebagian besar wilayah Indonesia masih berupa pedesaan.

Salah satu wujud perhatian pemerintah yaitu dengan lahirnya Undang-Undang Nomor 6 Tahun 2014 tentang Desa untuk selanjutnya disebut UU Desa. UU Desa membawa harapan baru kepada desa. Ada perbedaan mendasar antara cara pandang dalam memaknai desa. Sebelum lahir UU Desa, sebelum lahirnya UU Desa asas yang digunakan adalah prinsip Desentralisasi dan residualitas, Pemaknaan desa dalam UU Desa mempunyai prinsip Rekognisi dan subsidiaritas. Maksud dari asas Rekognisi adalah pengakuan terhadap hak asal usul desa dan ini merupakan

\footnotetext{
${ }^{51}$ https://id.wikipedia.org/wiki/Indonesia di akses tanggal 17 Agustus 2018.

${ }^{52}$ https://id.wikipedia.org/wiki/Daftar_kecamata n_dan_kelurahan_di_Indonesia, di akses tanggal 17 Agustus 2018.
}

bentuk penghormatan terhadap Desa, sesuai dengan semangat UUD 1945 Pasal 18 B ayat 2 yang memberikan pengakuan dan penghormatan terhadap kesatuan masyarakat hukum adat beserta hak-hak tradisionalnya.

Asas subsidiaritas menurut Sutoro Eko memiliki tiga makna antara lain; Pertama, subsidiaritas adalah kewenangan yang dimiliki oleh desa dalam mengambil keputusan atau kebijakan berkaitan dengan kepentingan masyarakat desa. Pemaknaan yang ke kedua, desa mempunyai kewenangan lokal berskala desa, yang ditetapkan dengan peraturan menjadi kewenangan desa, dari pengertian ini, desa mempunyai hak penuh untuk mengatur hal-hal yang menjadi kewenangan tersebut. Ketiga, Desa mempunyai kuasa penuh untuk mengatur desanya sesuai dengan kewenangan lokal desa, pemerintah tidak berhak mencampuri atau mengintervensi, pemerintah hanya bisa memberikan dukungan, dorongan dan fasilitasi terhadap desa, dalam melaksanakan kewenangan desa, atau dalam mengatur dan mengurus kepentingan masyarakat setempat ${ }^{53}$.

Untuk melaksanakan tugas dan fungsi desa dalam bidang penyelenggaraan pemerintah desa, bidang pembangunan desa, bidang pembinaan kemasyarakatan dan bidang pemberdayaan sesuai dengan kewenangan yang dimiliki, UU Desa memberikan mandat kepada Pemerintah untuk mengalokasikan Dana Desa ke setiap desa seluruh Indonesia. Dana

\footnotetext{
${ }^{53}$ Mochammad Zaini Mustaqim, “Kepemimpinan Desa”, Kementerian Desa, Pembangunan Daerah Tertinggal dan Transmigrasi, Jakarta, 2015, hlm. 11.
} 
desa tersebut dianggarkan setiap tahun dalam APBN yang diberikan kepada desa sebagai salah satu sumber pendapatan desa.

Pada tahun 2017 peraturan yang mengatur prioritas penggunaan dana desa adalah Peraturan Menteri Desa, Pembangunan Daerah Tertinggal, dan Transmigrasi No 22 Tahun 2016 tentang Penetapan Prioritas Penggunaan Dana Desa Tahun 2017. Ditegaskan dalam Pasal 4 bahwa Prioritas Penggunaan Dana Desa untuk membiayai pelaksanaan program dan kegiatan di bidang Pembangunan Desa dan Pemberdayaan Masyarakat Desa. Namun pada bulan april tahun 2017 peraturan tersebut telah diubah dengan peraturan baru yaitu Nomor 4 Tahun 2017 Tentang Perubahan Atas Peraturan Menteri Desa, Pembangunan Daerah Tertinggal, dan Transmigrasi Nomor 22 Tahun 2016 Tentang Penetapan Prioritas Penggunaan Dana Desa Tahun 2017, ada beberapa perubahan mendasar yaitu berkaitan prioritas penggunaan dana desa, sebagaimana yang telah diubah dalam Pasal 4 sehingga berbunyi sebagai berikut:

Pasal 4 (1) Prioritas Penggunaan Dana Desa untuk membiayai pelaksanaan program dan kegiatan di bidang Pembangunan Desa dan Pemberdayaan Masyarakat Desa. (2) Priroritas penggunaan dana Desa diutamakan untuk membiayai pelaksanaan program dan kegiatan yang bersifat lintas bidang. (3) Program dan kegiatan sebagaimana dimaksud pada ayat (2) terutama bidang kegiatan BUMDesa atau BUMDesa Bersama, embung, produk unggulan Desa atau kawasan perdesaan dan sarana olahraga Desa. (4) Prioritas penggunaaan dana Desa sebagaimana dimaksud pada ayat (1), dipublikasikan kepada masyarakat oleh Pemerintah Desa di ruang publik atau ruang yang dapat diakses masyarakat Desa.

Prioritas penggunaan dana desa tahun 2017 sebelum ada perubahan maupun setelah ada perubahan dalam hal pembidangan kegiatan tidak ada perbedaan. Dana desa hanya dapat digunakan untuk membiayai kegiatan pembangunan desa dan pemberdayaan masyarakat.

Desa Kancilan sebagai salah satu desa penerima dana desa wajib melaksanakan apa yang diamanatkan oleh UU Desa serta peraturan dibawahnya. Pada tahun 2017 dana desa yang diterima desa Kancilan sebesar Rp. 912.875.000,- dana tersebut digunakan untuk membiayai kegiatan dalam bidang pembangunan desa dan pemberdayaan, dalam pelaksanaan kegiatan pembangunan.

Pemerintah desa Kancilan dalam mengimplementasikan kegiatan pembangunan desa lebih banyak melakukan pembangunan fisik seperti pembangunan jalan, saluran irigasi dan talud, sedangkan kegiatan yang dilakukan dalam bidang pemberdayaan masyarakat meliputi pemberdayaan posyandu, pemuda dan karang taruna.

Kajian mengenai dana desa merupakan kajian baru dan menarik, baik dalam perencanaan penggunaan dana desa maupun pelaksanaannya, karena desa yang ada sekian lama baru tahun 2015 mendapatkan perhatian khusus dengan pengglontoran dana desa sehingga disusunlah penelitian yang berjudul "Implementasi Dana Desa Dalam Pelaksanaan Pembangunan Desa dan Pemberdayaan Masyarakat (Best Practice di Desa Kancilan Tahun 2017)".

Melihat latar belakang yang sudah diuraikan di atas, maka muncul 
permasalahan yang perlu mendapatkan pemecahan, yaitu:

1) Bagaimana proses perencanaan dalam kegiatan pembangunan desa dan pemberdayaan masyarakat di Desa Kancilan Tahun 2017?

2) Bagaimana pelaksanaan dana desa yang dipergunakan untuk kegiatan pembangunan desa dan pemberdayaan masyarakat desa di desa Kancilan tahun 2017?

\section{METODE PENELITIAN}

Menurut Sugiyono Metode penelitian adalah cara-cara ilmiah untuk mendapatkan data yang valid, dengan tujuan dapat ditemukan, dikembangkan, dan dibuktikan sehingga dapat digunakan untuk memahami, memecahkan, dan mengantisipasi masalah $^{54}$.

Menurut Komisi Etika Penelitian Unika Atma Jaya Jakarta, penelitian adalah kegiatan rasional, metodologis dan sistematis untuk menghasilkan pengetahuan ilmiah, kegiatan penelitian tersebut mecakup perumusan masalah, membangun hipotesis, mengumpulkan, mengolah, dan menganalisis data serta menyimpulkannya ${ }^{55}$.

Penelitian ini meliputi pendekatan masalah, spesifikasi penelitian, spesifikasi penelitian, jenis data, metode pengumpulan data dan analisa data. ${ }^{56}$

Metode yang digunakan dalam penelitian ini termasuk jenis penelitian hukum yuridis empiris yaitu penelitian hukum yang obyek kajiannya meliputi ketentuan perundang-undangan dan

\footnotetext{
${ }^{54}$ Jonaedi Efendi dan Johnny Ibrahim, "Metode Penelitian Hukum Normatif dan Empiris", Prenadamedia Grup, Depok, 2018, hlm. 2-3

${ }^{55}$ Rianto Adi, "Aspek Hukum Dalam Penelitian”, Yayasan Pustaka Obor Indonesia, Jakarta, 2015, hlm. 1.

${ }^{56}$ Soerjono Soekanto, 2016, Pengantar Penelitian Hukum, UI Press, Jakarta, hlm.7
}

penerapannya pada peristiwa hukum. Fokus penelitian hukum yuridis empiris adalah pada penerapan atau implementasi ketentuan hukum normatif (in abstracto) pada peristiwa hukum tertentu (in concreto) dan hasilnya $^{57}$

Spesifikasi penelitian ini bersifat diskriptif Analitis. Penelitian ini bertujuan untuk memperoleh gambaran (deskripsi) lengkap terhadap peristiwa hukum berdasarkan hasil kajian komprehesif untuk menjawab permasalahan yang tertuang dalam rumusan masalah. ${ }^{58}$

Jenis data yang akan digunakan dalam penelitian ini berupa data primer dan data sekunder. Data primer diperoleh dari dari masyarakat yang dikumpulkan melalui wawancara dengan responden atau informan, sedangkan data sekunder terdiri dari bahan hukum primer dan bahan hukum sekunder.

\section{HASIL PENELITIAN DAN PEMBAHASAN}

1. Proses perencanaan dalam kegiatan pembangunan desa dan pemberdayaan masyarakat di Desa Kancilan Tahun 2017

Proses perencanaan dan pelaksanaan di desa Kancilan mengacu kepada dua dokumen yaitu RPJMDesa dan RKPDesa. Hal ini sesuai dengan Permendagri Nomor 114 Tahun 2014 pasal 5 yang menyebutkan bahwa Perencanaan pembangunan Desa disusun secara berjangka meliputi: RPJMDesa dan RKPDesa. Meskipun belum sempurna kedua dokumen

\footnotetext{
${ }^{57}$ Abdulkadir Muhammad, "Hukum dan Penelitian Hukum”, PT Citra Aditya Bakti, Bandung, 2004, hlm 136.

${ }^{58} \mathrm{H}$. Zainuddin Ali, Metode Penelitian hukum, Sinar Grafika, 2010, Jakarta, hlm.19
} 
perencanaan tersebut sudah disusun oleh pemerintah desa Kancilan.

1) Rencana Pembangunan Jangka Menengah Desa (RPJMDesa)

Pemerintah desa Kancilan menyusun RPJMDesa pada tahun 2014 dengan membentuk tim yang berjumlah 11 orang, tim tersebut terdiri dari unsur perangkat desa, tokoh masyarakat, KPMD, anggota LKMD, Ketua TPK dan perwakilan kelompok perempuan ${ }^{59}$. Berdasarkan Surat Keputusan Petinggi desa Kancilan Nomor 11 Tahun 2014 tentang Pembentukan Tim Penyusun RKPdes dan RPJMDes Desa Kancilan Tahun 2014.

Struktur tim yang dibentuk, sesuai dengan Permendagri 114 Tahun 2014 Pasal 8, yang menyebutkan bahwa Kepala Desa membentuk tim penyusun RPJM Desa yang terdiri dari Kepala desa selaku Pembina, carik selaku ketua, ketua lembaga pemberdayaan masyarakat selaku sekretaris dan anggota yang berasal dari perangkat Desa, lembaga pemberdayaan masyarakat, kader pemberdayaan masyarakat Desa, dan unsur masyarakat lainnya serta mengikutsertakan unsur perempuan dalam tim tersebut.

Berdasarkan hasil wawancara dengan evaningsih dan Sudarbi selaku Carik desa Kancilan, Proses penyusunan RPJMDesa dilakukan dengan identifikasi potensi desa oleh tim penyusun, data-data yang diperoleh terkait Kondisi Geografis, monografi desa, data kelembagaan pemerintahan desa, data-data tersebut yang menjadi

59 Evaningsih, "Wawancara Pribadi", Tim Penyusun RPJMDesa, 14 Agustus 2018, Kancilan Jepara acuan tim penyusun dalam mengkaji dan menyusun RPJMDesa ${ }^{60}$.

RPJMDesa Kancilan memuat program-program dalam bidang infrastruktur, bidang pendidikan, bidang kesehatan, bidang ekonomi, bidang budaya dan agama. Selanjutnya akan diurai lebih jelas di bawah ini:

a. Bidang Infrastruktur

Beberapa infrastruktur yang mendapat prioritas pembangunan diantaranya: Pembangunan Balai desa, Pembanguan Kantor BPD, LKMD, Karang Taruna, PKK, Linmas dan PKD, Pembangunan Jalan, Perbaikan Drainase dan Perbaikan Jembatan.

b. Bidang Pendidikan

Beberapa bidang pendidikan yang mendapat prioritas diantaranya: Pembangunan Gedung TK, TPQ, Madin, Insentif Guru TK, TPQ, Madin dan Perpustakaan Desa.

c. Bidang Kesehatan

Kegiatan dalam bidang kesehatan yang menjadi priorotas dalam RPJMDesa meliputi: Posyandu Lansia, Pemberantasan Nyamuk dan Pembangunan Sanitasi.

d. Bidang Ekonomi

Bidang ekonomi yang menjadi prioritas dalam RPJMDesa meliputi: Pasar Desa, Pengadaan Sarana Mesin Pengolah Sampah dan Kotoran Ternak dan Keramba Ikan.

e. Bidang Budaya

Prioritas kegiatan bidang budaya dalam RPJMDesa yaitu Sedekah Bumi dan Kesenian Tari Tradisional.

f. Bidang Agama

Beberapa bidang agama yang mendapat prioritas RPJMDesa diantaranya: Rehabilitasi Sarana

60 Evaningsih dan sudarbi, "Wawancara Pribadi”, Tim Penyusun RPJMDesa, 14 Agustus 2018, Kancilan Jepara 
Peribadatan, Pembangunan Gedung TPQ dan Madin dan Peringatan Hari Besar Agama.

Berdasarkan hasil analisa terhadap RPJMDesa Kancilan, khususnya dalam program pembangunan desa, ada ketidaksesuaian antara RPJMDesa dengan aturan ideal RPJMDesa yang diatur oleh Permendagri 114 tahun 2014 tentang Pedoman Pembangunan Desa. Kalau mengacu pada Permendagri 114, arah kebijakan pembangunan Desa meliputi bidang penyelenggaraan Pemerintahan Desa, pelaksanaan pembangunan Desa, pembinaan kemasyarakatan Desa, dan pemberdayaan masyarakat Desa. Jika dikelompokkan maka idealnya uraian kebijakan pembangunan desa Kancilan seperti di bawah ini:

a. Bidang Penyelenggaraan Pemerintahan Desa meliputi : Pembangunan Balai Desa, Penghasilan tetap petinggi dan perangkat, Tambahan tunjangan petinggi dan perangkat, Operasional BPD, Operasional Rt atau $\mathrm{Rw}$, Operasional perkantoran dan kegiatan lain yang menjadi ruang lingkup pemerintahan desa.

b. Bidang Pembangunan Desa meliputi : Pembanguan Kantor BPD, LKMD, Karang Taruna, PKK, Linmas dan PKD, Pembangunan Jalan, Perbaikan drainase, Perbaikan Jembatan, Pembangunan gedung TK, TPQ dan Madin, Perpustakaan desa, Posyandu Lansia, Pembangunan sanitasi, Pasar desa, Pengadaan sarana mesin pengolah sampah dan kotoran ternak danKeramba ikan.

c. Bidang Pembinaan Kemasyarakatan meliputi kegiatan Sedekah bumi, Kesenian tari tradisional, Rehabilitasi sarana peribadatan dan Peringatan hari besar agama,

d. Bidang Pemberdayaan Masayarakat meliputi kegiatan Insentif guru TK, TPQ, Madin dan Voging atau Pemberantasan nyamuk.

RPJMdesa Kancilan memang belum sesuai dengan peraturan yang ada, belum mengacu pada Permendagri 114 tahun 2014, namun dalam hal perencanaan dilakukan secara partisipatif dengan melibatkan elemen masyarakat.

Hasil pencermatan RPJMDesa desa Kancilan, pengesahan RPJMDesa melalui musyawarah yang diselenggarakan oleh pemerintah desa kancilan, hal tersebut bisa dilihat dalam lampiran berita acara dan daftar hadir, seharusnya jika mengikuti peraturan Permendagri 114 Tahun 2014 Pasal 25 yang mengatur tentang pengesahan RPJMDesa, pasal tersebut menyebutkan bahwa pengesahan RPJMDesa harus diselenggarakan melalui musyawarah perencanaan pembangunan Desa yang diadakan untuk membahas dan menyepakati rancangan RPJM Desa.

2) Rencana Kerja Pemerintah Desa (RKPDesa)

Rencana Kerja Pemerintah Desa, selanjutnya disingkat RKP Desa, adalah penjabaran dari RPJM Desa untuk jangka waktu 1 (satu) tahun. Dalam penyusunan RKPDesa tahun 2017 di desa Kancilan melalui proses partisipatif, maksudnya masyarakat terlibat langsung dalam musyawarah untuk perencanaan RKPDesa. Hal tersebut di sampaikan oleh Hartas selaku Kader Pemberdayaan Masyarakat Desa (KPMD), sebagai KPMD yang kami lakukan yaitu melakukan penggalian gagasan di setiap lingkungan yaitu $44 \mathrm{Rt}$ dan $9 \mathrm{Rw}$ yang ada di desa Kancilan, sesuai tugas kami 
kegiatan penggalian gagasan ini dilakukan agar kegiatan di desa Kancilan tepat sasaran.

Kegiatan penggalian gagasan bertujuan untuk menggali keinginan dan kebutuhan masyarakat setempat agar arah kebijakan desa tidak jauh dari yang dibutuhkan masyarakat, penggalian gagasan oleh KPMD dilakukan dengan cara mengikuti forum musyawarah di tingkat Rt. musyawah tersebut khusus untuk membahas perencanaan kegiatan yang dibutuhkan masyarakat, seluruh usulan dari masyarakat ditampung keseluruhan oleh KPMD setelah itu ditetapkan skala prioritas secara musyawarah. $^{61}$

Salah satu cara yang dilakukan KPMD agar tidak terjadi hal-hal yang tidak diinginkan dikemudian hari, KPMD dalam setiap kegiatan penggalian gagasan meminta persetujuan seluruh anggota musyawarah, biasanya yang menyangkut kegiatan pembangunan KPMD membuat surat pernyataan bermaterai yang menyatakan menyetujui usulan pembangunan di wilayah tersebut, serta tidak akan menuntut ganti rugi atas tanah jika usulan pembangunan direalisasikan oleh pemerintah desa Kancilan.

KPMD juga mempunyai peta disetiap RT se-desa Kancilan, peta itu sebagai acuan KPMD dalam mengakomodir usulan dari masyarakat, Usulan dari masyarakat yang masuk dalam penggalian gagasan kebanyakan pembangunan fisik, yang menyangkut usulan pemberdayaan masih sangat sedikit.

61 Hartas, “Wawancara Pribadi”, Anggota Kader Pembedayaan Masyarakat Desa (KPMD), 2 Agustus 2018, Kancilan Jepara
Setelah penggalian gagasan yang di lakukan KPMD selesai, Badan Permusyawaratan Desa selanjutnya disingkat BPD menyelenggarakan musyawarah desa untuk pembentukan tim penyusun RKPDesa, seluruh hasil penggalian gagasan yang dilakukan oleh KPMD secara keseluruhan dibacakan oleh KPMD dalam forum Musrenbangdes, hal ini dimaksudkan supaya masyarakat benar-benar tahu bahwa usulan tersebut di usulkan sendiri oleh lingkungan sekitar, dan jika ada usulan-usulan yang terlewat bisa diusulkan dalam forum tersebut. ${ }^{62}$

Menurut Sudarbi selaku Carik sekaligus sebagai ketua tim penyusunan RKPDesa menyatakan penyusunan RKPDesa tahun 2017 agak mengalami keterambatan karena terlambatnya informasi dari pemerintah daerah kabupaten berkaitan dengan pagu indikatif Desa dan rencana kegiatan Pemerintah baik program kegiatan dari pemerintah daerah provinsi maupun dan pemerintah daerah kabupaten. Idealnya RKPdes tahun 2017 maksimal ditetapkan akhir bulan september 2016 namun realita di desa Kancilan baru ditetapkan bulan februari tahun $2017^{63}$.

RKPDesa yang sudah disahkan menjadi pijakan dan acuan pemerintah desa Kancilan dalam menetapkan APBDesa, semua kegiatan yang ada dalam APBDesa harus masuk dalam matrik RKPDesa. Antara RPJMDesa, RKPDesa dan APBDesa harus sinkron jika tidak ada kesesuaian maka harus diadakan perubahan.

\footnotetext{
62 Yuswoto, "Wawancara Pribadi", Petinggi desa Kancilan, 14 Agustus 2018, Kancilan Jepara

${ }^{63}$ Sudarbi, "Wawancara Pribadi", Carik Desa Kancilan, 10 Agustus 2018, Kancilan Jepara
} 
2. Pelaksanaan dana desa yang dipergunakan untuk kegiatan pembangunan desa dan pemberdayaan masyarakat desa di desa kancilan tahun 2017.

Tahun 2017 desa Kancilan mendapatkan dana desa Rp. 912.875.000, sesuai peruntukannya, dana tersebut digunakan untuk membiayai kegiatan pembangunan desa dan pemberdayaan masyarakat.

Berdasarkan wawancara dengan Yunita selaku bendahara desa Kancilan, pencairan dana desa desa Kancilan tahap pertama $60 \%$ Rp. 547.725 .000 masuk ke rekening kas umum desa pada tanggal 30 Mei 2017, sedangkan tahap dua $40 \%$ sebesar Rp. 365.150 .000 masuk ke rekening kas umum desa pada tanggal 27 Oktober 2017.

Penggunaan dana desa tahun 2017 di desa Kancilan akan dibahas lebih rinci di bawah ini:

1) Pelaksanaan dana desa dalam bidang pembangunan desa

Dana desa yang digunakan untuk pelaksanaan bidang pembangunan di desa Kancilan tahun 2017 sebesar 96,44\% yakni Rp. 880.335.000, secara keseluruhan dana desa desa yang digunakan dalam pembangunan desa sebesar 895.026.500, dana tersebut bersumber dari dana desa tahun 2017 sebesar Rp. 880.335.000,-, dan silpa dana desa tahun 2016 sebesar Rp. 14.691.500, secara keseluruhan dana desa tahun 2017 dan silpa dana desa tahun 2016 digunakan untuk membiayai 37 kegiatan, yang terdiri dari 35 pembangunan fisik dan 2 kegiatan berupa kegiatan non fisik.

Keseluruhan kegiatan pembangunan di desa Kancilan sudah sesuai dengan kewenangan lokal berskala desa. Namun sebelum penetapan kegiatan seharusnya ada peraturan desa yang mengatur tentang kewenangan berdasarkan hak asal usul desa dan kewenangan lokal berskala desa, namun petinggi tidak mengeluarkan perdes tersebut.

Dana desa di desa Kancilan tahun 2017 terserap 100\%, Penggunaan dana desa di desa Kancilan tahun 2017 lebih banyak digunakan untuk membiayai pembangunan infrastruktur desa, yang bertujuan untuk memperlancar arus transportasi, seperti disampaikan oleh Yuswoto selaku Petinggi desa Kancilan.

Dalam pelaksanaan pembangunan unsur kelembagaan desa yang terlibat yaitu BPD dan LKMD, kedua lembaga tersebut menjadi pengawas selama kegiatan pembangunan berlangsung, BPD terlibat aktif dalam pengawas pembangunan koordinasi dengan pemerintah desa juga baik.

Masyarakat juga dilibatkan dalam pelaksanaan pembangunan desa, salah satu pelibatan masyarakat yaitu dengan dibentuknya tim pengelola kegiatan selanjutnya disingkat TPK ataupun tim pelaksana kegiatan pembangunan. TPK mempunyai peran yang sangat penting dalam pembangunan, kegiatan yang dilakukan TPK mulai pra kegiatan, pelaksanaan kegiatan, pertanggungjawaban dan serah terima pekerjaan kalau proyek tersebut sudah selesai.

Keterbatasan SDM TPK menjadi kendala dalam perencanaan pembangunan, bahwa dalam perencanaan kegiatan pembangunan salah satu tugas TPK adalah membuat rencana anggaran biaya (RAB), yang dijadikan pedoman atau acuan dalam pelaksanaan pembangunan, namun RAB tersebut tidak dibuat oleh TPK karena ketidakmampuan TPK dalam penyusunanya sehingga tugas yang seharusnya menjadi tugas TPK di 
alihkan kepada Kaur Perencanaan desa Kancilan yang mempunyai latar belakang pendidikan tehnik ${ }^{64}$.

Semua kegiatan pembangunan di desa Kancilan dilakukan secara swakelola, bahkan kegiatan pengaspalan jalanpun dengan swakelola, kebetulan banyak masyarakat desa kancilan yang mempunyai keahlian tenaga pengaspalan jalan, dengan peralatan yang disewa, menurut ketua Tupiyono selaku TPK semua kegiatan pembangunan menggunakan prinsip swakelola dengan mempertimbangkan prinsip efisiensi dan efektivitas, sebagian warga dilibatkan sebagai pekerja dengan upah disesuaikan dengan standart desa, sebagian warga yang lain sebagai tenaga sukarela atau gotong royong, sebagian juga ada yang menyediakan konsumsi untuk pekerja ${ }^{65}$.

Setiap kegiatan pembangunan, TPK memasang papan proyek kegiatan, di dalam papan tersebut berisi bentuk kegiatan, waktu pelaksanaan, nominal biaya dan sumber dana. "setiap kegiatan kami pasang banner untuk publikasi kepada masyarakat, biar masyarakat tahu besarnya anggaran yang digunakan dalam kegiatan tersebut" ${ }^{\text {,66. }}$.

Selain itu, upaya transparansi anggaran juga dilakukan Pemerintah Desa kancilan dengan memasang banner berisi infografis APBDesa di ruang publik atau ruang yang dapat diakses masyarakat desa. di dalamnya terdapat sumber pendapatan, bentuk

\footnotetext{
${ }^{64}$ Tupiyono, “Wawancara Pribadi”, Ketua TPK Desa kancilan, 12 Juli 2018, Kancilan Kembang Jepara

${ }^{65}$ Tupiyono, “Wawancara Pribadi”, Ketua TPK Desa kancilan, 12 Juli 2018, Kancilan Kembang Jepara

${ }^{66}$ Tupiyono, "Wawancara Pribadi”, Ketua TPK Desa kancilan, 12 Juli 2018, Kancilan Kembang Jepara
}

kegiatan beserta anggaran dananya, masyarakat akan mudah mengakses atau mengetahui kegiatan apa saja yang akan dilaksanakan tahun 2017, sehingga masyarakat bisa turut serta dalam pelaksanaan dan pengawasan kegiatan pembangunan.

Berdasarkan hasil wawancara dengan sepuluh orang mewakili masyarakat desa Kancilan, Manfaat pembangunan dirasakan betul oleh masyarakat, semua menyatakan turut senang karena infrastruktur desa menjadi lebih baik.

Pembangunan di desa Kancilan berasal dari kehendak masyarakat melalui penggalian gagasan, baik secara langsung maupun tidak langsung kegiatan pembangunan desa berdampak pada peningkatan ekonomi masyarakat, dengan adanya 35 kegiatan fisik yang dilakukan pemerintah desa Kancilan secara angsung menyerap tenaga kerja lokal dan memberikan tambahan penghasilan , dengan kegiatan pembangunan sarana dan prasarana, menjadikan transportasi menjadi lebih baik, bagi para petani pengangkutan hasil panen menjadi semakin mudah.

Secara tidak langsung keberadaan dana desa mempunyai dampak sosial yang baik, dalam perencanaan terjadi interaksi antar masyarakat untuk bermusyawarah baik lingkup Rt maupun $\mathrm{Rw}$ untuk menetapkan usulan kegiatan, selain itu muncul semangat gotong royong maupun swadaya dari masyarakat, karena mereka sadar betul apa yang mereka usulkan menjadi kebutuhan.

2) Pelaksanaan dana desa dalam bidang pemberdayaan masyarakat Kegiatan pemberdayaan masyarakat desa Kancilan tahun 2017 yang bersumber dari dana desa Rp. 32.540.000, kegiatan tersebut digunakan 
untuk 3 kegiatan, yaitu kegiatan posyandu balita, posyandu lansia dan kegiatan pemuda dan olahraga. Prosentase dari total dana desa yang diterima pemerintah desa Kancilan yang dipergunakan untuk kegiatan pemberdayaan $3,56 \%$, Berdasarkan hasil wawancara dengan kader Posyandu Mekar Lestari 2 Ibu Sutimah, Kegiatan Posyandu merupakan kegiatan yang sangat penting, di dalamnya terdapat kegiatan tambah gizi, deteksi tumbuh kembang anak, pemeriksaan kesehatan, parenting, sharing tentang pola asuh anak dan pola hidup sehat. "kita dapat anggaran dari desa, kita gunakan untuk uang saku kader, rapat kader posyandu dan pemeriksaan laborat sederhana" setiap kegiatan posyandu pasti ada menu makanan tambahan untuk balita, yang ada anggaran dari desa untuk makanan tambahan hanya posyandu lansia, sedangkan untuk posyandu balita murni swadaya dari anggota posyandu, tiap pertemuan posyandu balita orang tua membayar Rp. 2000,- untuk pengganti makanan tambahan.

Menurut penulis ada beberapa catatan berkaitan dengan kegiatan pemberdayaan masyarakat di desa Kancilan diantaranya yaitu, belum adanya anggaran pemberdayaan bagi masyarakat yang mengalami cacat mental maupun fisik, berdasarkan data profil desa tahun 2017 di desa Kancilan ada 36 orang yang mengalami cacat mental maupun fisik dan belum tersentuh anggaran dari desa, seharusnya mereka juga perlu mendapatkan hak anggaran sesuai yang di atur dalam Permendesa Nomor 22 Tahun 2016 pasal 3 huruf a "Prioritas penggunaan Dana Desa didasarkan pada prinsip keadilan dengan mengutamakan hak dan kepentingan seluruh warga Desa tanpa membeda-bedakan”.

\section{Kesimpulan}

Berdasarkan hasil penelitian yang sudah dilakukan penulis dapat ditarik kesimpulan sebagai berikut:

1) Proses perencanaan pembangunan desa dan pemberdayaan masyarakat mengacu pada dokumen RPJMDesa dan RKPDesa, dalam perencanaan sudah ditetapkan melalui forum musyawarah, meskipun ada beberapa catatan dalam perencanaan, yaitu:

a. Dokumen RPJMDesa yang ada di desa Kancilan belum sesuai dengan permendagri 114 tahun 2014, matrik yang ada dalam lampiran RPJMDesa belum sesuai dengan peraturan yang ada.

b. Proses penyusunan RKPDesa belum sesuai prosedur, ketidaksesuaian proses dalam penyusunan RKPDesa, kalau mengacu pada peraturan Permendagri 114 tahun 2014 tentang pedoman pembangunan desa, tidak ada sedikitpun kalimat penggalian gagasan dalam penyusunan RKPDesa, yang ada penggalian gagasan itu dilakukan saat penyusunan RPJMDes yaitu dilakukan saat pengkajian keadaan desa, yang dilakukan tim penyusun RKPDesa hanya sebatas pencermatan program yang direncanakan dalam RPJMDes bukan penggalian gagasan ulang.

2) Pelaksanaan kegiatan pembangunan dan pemberdayaan sesuai dengan kewenangan lokal berskala desa, hanya saja ada prosentase yang tidak berimbang dalam penyerapan 
anggaran, kegiatan pembangunan desa sebesar $96,44 \%$ yakni $\mathrm{Rp}$. 880.335.000, sedangkan untuk kegiatan pemberdayaan masyarakat sebesar 3,65\% yakni Rp. 32.540.000, hal tersebut dikarenakan usulan masyarakat yang masuk dalam perencanaan kebanyakan pembangunan fisik.

\section{Saran}

Saran dan masukan setelah melakukan penelitian ini yaitu:

1) Pentingnya peningkatan kapasitas bagi perangkat desa dan pelaku kegiatan di desa agar memahami juknis baik dalam perencanaan, pelaksanaan maupun evaluasi

2) Adanya affirmative action dari pemrintah pusat untuk memprioritaskan penggunaan dana desa untuk kegiatan pemberdayaan masyarakat.

\section{DAFTAR PUSTAKA}

Abdulkadir Muhammad, "Hukum dan Penelitian Hukum”, PT Citra Aditya Bakti, Bandung, 2004
H. Zainuddin Ali, Metode Penelitian hukum, Sinar Grafika, 2010, Jakarta

Jonaedi Efendi dan Johnny Ibrahim, 2018, "Metode Penelitian Hukum Normatif dan Empiris", Prenadamedia Grup, Depok.

Mochammad Zaini Mustaqim, 2015, "Kepemimpinan Desa",

Kementerian Desa, Pembangunan Daerah Tertinggal dan Transmigrasi, Jakarta.

Rianto Adi, 2015, “Aspek Hukum Dalam Penelitian”, Yayasan Pustaka Obor Indonesia, Jakarta.

Soerjono Soekanto, 2016, Pengantar Penelitian Hukum, UI Press, Jakarta

\section{Internet :}

https://id.wikipedia.org/wiki/Indonesia di akses tanggal 17 Agustus 2018. https://id.wikipedia.org/wiki/Daftar_kec amatan_dan_kelurahan_di_Indone sia, di akses tanggal 17 Agustus 2018. 